Journal of Southeast Asian

\title{
'in Gram's blouse pocket - trong túi áo Ngoại'
}

Trangdai Glassey-Tranguyen

Vietnamese Diasporas Projects, vietamproj@gmail.com

Follow this and additional works at: https://docs.lib.purdue.edu/jsaaea

Part of the Bilingual, Multilingual, and Multicultural Education Commons

\section{Recommended Citation}

Glassey-Tranguyen, Trangdai (2020) "'in Gram's blouse pocket - trong túi áo Ngoại'," Journal of Southeast Asian American Education and Advancement. Vol. 15 : Iss. 1, Article 3.

DOI: $10.7771 / 2153-8999.1190$

Available at: https://docs.lib.purdue.edu/jsaaea/vol15/iss1/3

This document has been made available through Purdue e-Pubs, a service of the Purdue University Libraries. Please contact epubs@purdue.edu for additional information.

This is an Open Access journal. This means that it uses a funding model that does not charge readers or their institutions for access. Readers may freely read, download, copy, distribute, print, search, or link to the full texts of articles. This journal is covered under the CC BY-NC-ND license. 


\title{
USAAEA Journal of Southeast Asian American Education and Advancement
}

Vol. 15 Iss. 1 (2020)

\author{
WWW.JSAAEA.org
}

\section{In Gram's Blouse Pocket-Trong túi áo Ngoại \\ Six Selected Bilingual Poems \\ Sáu Bài Thơ Song Ngữ Chọn Lọc}

\author{
Trangđài Glassey-Trầnguyễn \\ *On the Sixth Anniversary of Ngoại's Passing* \\ * Nhân Lễ Giỗ Thứ Sáu của Ngoại *
}

\section{Poem 1: i didn’t cry—con đã không khóc}

i didn't cry

when i heard of your departure

it wasn't for good, was it?

you'll be there when i come home, won't you?

i didn't cry

i couldn't

i just stared at the ceiling

counting the ornamental beams

blanking out

how do i account

for all the years

i spent with you

the first two decades of my life

(and it didn't matter

that i wasn't your favorite)?

i didn't cry

i didn't

i felt the warmth of the freshly-boiled banana cakes,

your trade mark,

so sweet and tender

on my lips

\footnotetext{
(C)

SDIRERIGHISRESEREEDReaders are free to copy, display, and distribute this article, as long as the work is attributed to the author(s) and the Journal of Southeast Asian American Education \& Advancement, it is distributed for non-commercial purposes only, and no alteration or transformation is made in the work. More details of this Creative Commons license are available at http://creativecommons.org/licenses/by-nc-nd/3.0/. All other uses must be approved by the author(s) or JSAAEA. Journal of Southeast Asian American Education \& Advancement, Vol. 15. Iss. 1. (2020) ISSN: 2153-8999
} 


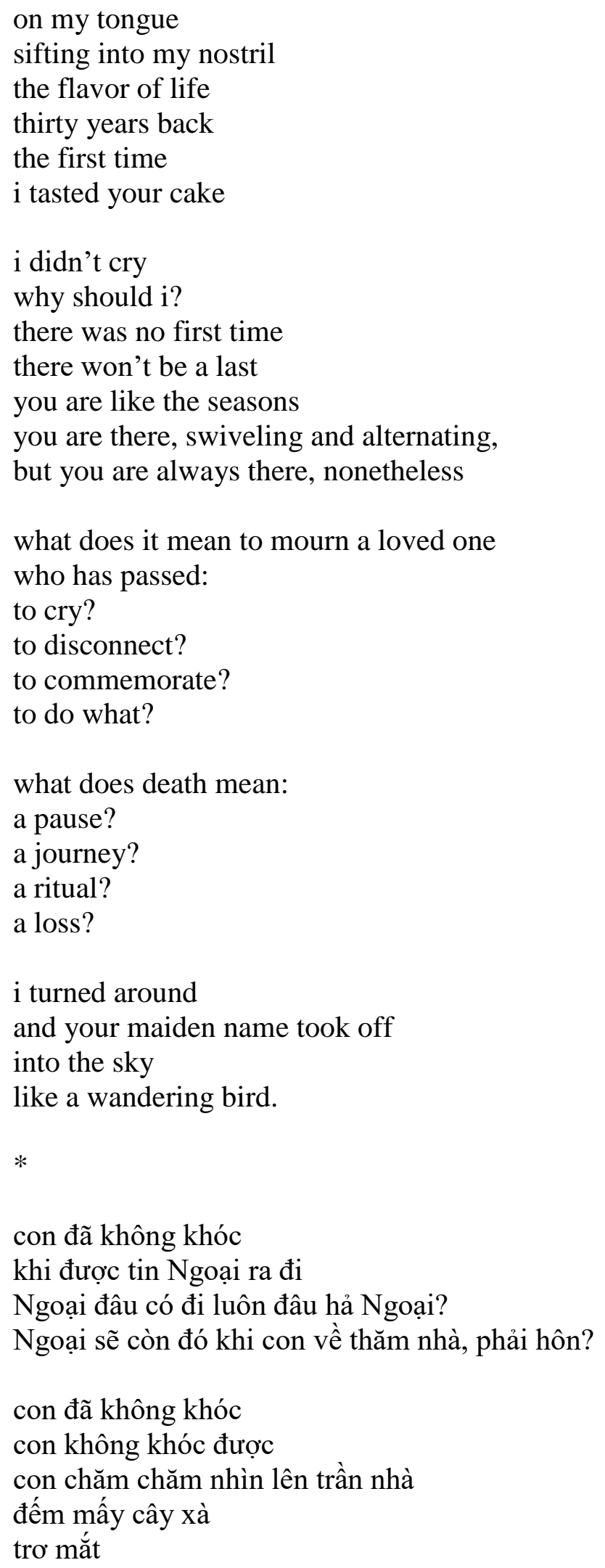




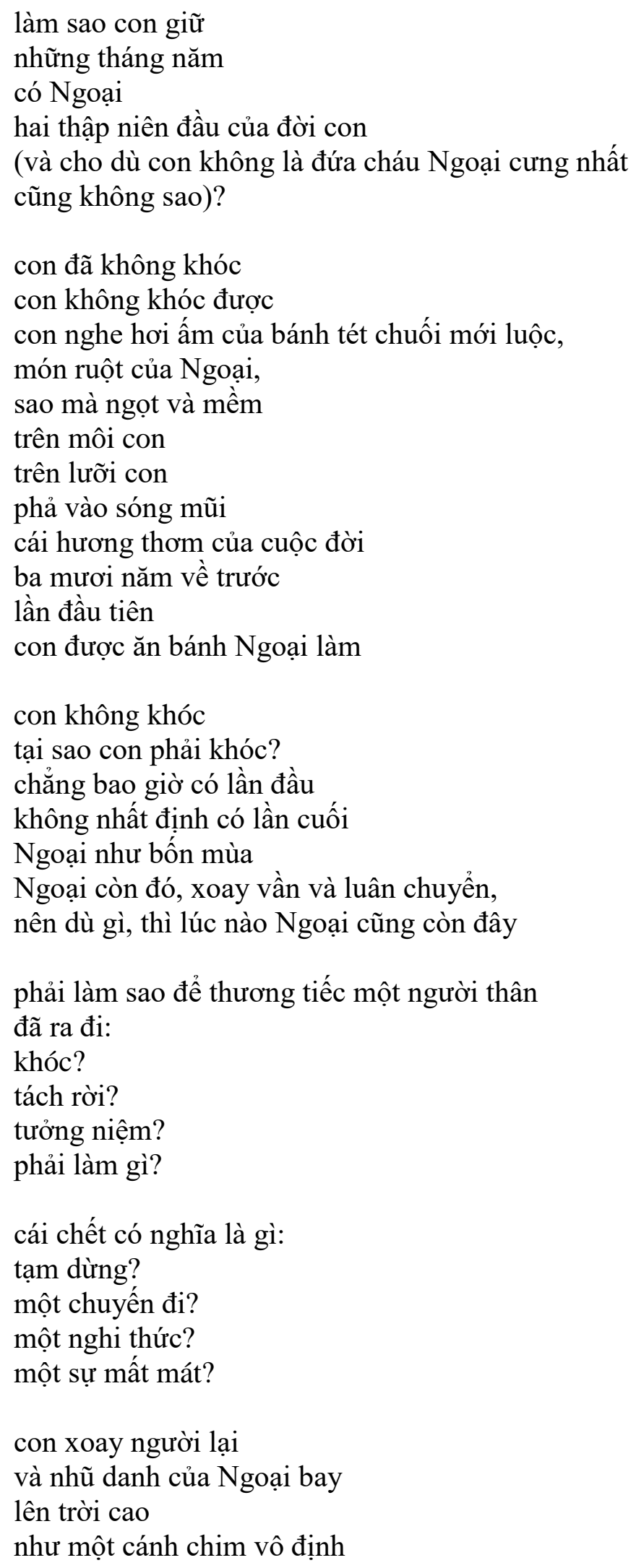




\section{Poem 2: the sound of mourning—tiếng thọ tang}

what is the sound of mourning?

or is it soundless?

what is it with all this chanting?

do you heed it?

how does the soul cry,

does it know how to weep?

You're dancing like a morning wind spreading quiet shafts.

$*$

có ai nghe được âm thanh tang chế không?

hay nó vô âm?

bao lời tụng niệm này để làm gì?

Ngoại có nghe được không?

linh hồn thổn thức ra sao, nó có biết khóc không?

Ngoại tung tăng như gió ban mai bung nắng lặng.

\section{Poem 3: the moment of halt—khoảng tịnh}

news of your passing arrived

putting all of life on hold

i was still

for three days

not knowing what to think

not knowing how to act

time was empty

the day void

my mind wandered in timelessness

life floated in another world

where you were making cakes

cooking noodles

farming

gardening

bathing us, grandchildren 
you were strong and middle-aged

you were charming and assertive

you were the matriarch

who worked and served her descendants

generation in, generation out,

the archetype of your time

the paragon of mine

in this moment of halt

life sits down

and rolls out her past

unfolding you

in motion

as if nothing had passed.

$*$

tin Ngoại mất

làm cả cuộc sống dừng lại

con bất động

trong suốt ba ngày

không biết phải nghĩ gì

không biết phải làm gì

thời gian rỗng

ngày trống

óc con lang thang trong miền không-thời-gian

nơi mà Ngoại đang làm bánh

nấu bún

làm ruộng

mần gò

tắm táp cho tụi con

Ngoại khỏe, đang tuổi trung tuần

Ngoại duyên dáng và dứt khóat

Ngoại là tổ mẫu

làm lụng vất vả để lo cho con cháu

hết đời này đến đời kia

Ngoại là khuôn mẫu của thời Ngoại

là mẫu mực của thời con

trong giây phút tịnh này

cuộc sống ngồi xuống

và giở lại quá khứ

có Ngoại 
vẫn như ngày nào như thể không có chuyện gì xảy ra ...

\section{Poem 4: the second anniversary—giỗ nhì}

* For Grandpa, as he entered his second year as a widower *

i kneeled - the mourning band on my head

$i$ rose - the second anniversary arrived

Ngoại left in a moonlight season

the season of broken-heartedness

of joy and sorrows

you've left behind

light and bright, you entered Truth

no more sufferings

you stayed in the hearts

of your kins and non-kins

your gravestone still lacks

his name who shared your life's burdens

who knows that taste of death

who fathoms the scent of mourning

who with tears streaming down two cheeks

preparing your second anniversary...

the living awaits the dead

twenty-four moon seasons

the wheel of time stops

when the incense takes flight

oh, second anniversary!

down came myrrh and smoke

words fail to express

when two persons, two worlds...

* Kinh tặng Ông Ngoại, năm thứ hai goá vọ *

vừa cúi đầu cài khăn

ngẩng đầu đã hai giỗ

Ngoại đi mùa tròn trăng

mùa yêu thương nức nở

những vui buồn, mất được

Ngoại để lại thế trần

nhẹ về cõi tòan-chân 
dứt hồng trần bể khổ

Ngoại ở lại trong lòng cả người thân, kẻ lạ mộ bia khuyết tên chồng cùng Ngoại đời vất vả

ai hiểu được vị chết

ai thấu được mùi tang ai nước mắt hai hàng lo giỗ nhì của Ngoại...

người sống chờ người chết hai mươi bốn con trăng bánh thời gian ngừng lăn khi trầm hương cất cánh

ôi, giỗ nhì cám cảnh nhang khói ngậm ngùi rơi nói bao cho cạn lời khi mỗi người một cõi...

\section{Poem 5: seeing Gram—về Ngoại}

tis been long seen i last saw my Gram

the soil paths are no longer

the tile-roof houses defeated the water-coconut-leaf homes

returning home, i find more strangers than neighbors

the memory pond is de-silted childhood awaits the falling stars

the Big River carries the high tides

the old water buffalo splashes out hay

the foretime fields are milkening

the sticky rice forgets the scent of its cakes

nostalgia grinds in the air

and sows tomorrow's threshold

i visit yore, i visit Gram

i haven't seen her grave, yet feeling like i've known it away from home, we love our host country a new spring nears, we're pining our birth home

this Tết, i'll be away again

i would still be estranged visiting your grave 
life paused at the news of your passing my heart lurked round the fields

my speech truncated and exerted

Gram is no longer, why shall i come home?

\author{
$*$ \\ lâu, chưa về thăm Ngoại \\ đường bờ con[i] không còn \\ nhà lá thua nhà ngói[ii] \\ đầu xóm thưa người quen \\ ao ký ức lóng phèn[iii] \\ tuổi thơ chờ sao rụng \\ sông Cái bưng[iv] nước lớn \\ con trâu già tạt $[\mathrm{v}]$ rơm \\ ruộng quá khứ trổ đòng[vi] \\ nếp quên mùi bánh tét[vii] \\ nỗi nhớ xay lơ lửng \\ gieo bực thềm tương lai \\ thăm ngày xưa, thăm Ngoại \\ mộ chưa viếng, đã quen \\ xa quê, yêu đất khách \\ gần xuân, xót quê nhà \\ Tết này con xa nữa \\ viếng mộ cũng lạc loài \\ hụt hẫng tin Bà mất \\ tim vất vưởng ngoài đồng \\ nói năng chừng chật vật \\ Ngoại không còn, thăm chi ...
}

[i] Đường đất nhỏ giữa các thửa ruộng. Tiếng địa phương vùng Bình Phú Đông, miền Tây Nam Bộ.

[ii] Trong áp lực 'hiện đại hóa,' người dân trong vùng đã tranh nhau xây nhà ngói và xi măng, không cất nhà lá như bao đời trước, làm mất hẳn nhân diện của một miền quê.

[iii] Ở miền quê của vùng nước lợ Gò Công, tỉnh Tiền Giang, người dân phải dùng hàn the để tẩy phèn trong nước cho sinh hoạt hằng ngày, để tránh tay chân và áo quần bị đóng phèn, bị vàng. [iv] Từ địa phương, thuộc miền Tây Nam nước Việt. Động từ: mang, bê, ẵm. Danh từ: mảnh ruộng gần sông.

[v] Từ địa phương, thuộc miền Tây Nam nước Việt. Động từ: hất chất lỏng đi từ một vật chứa (chẳng hạn như hất chất lỏng ra từ trong một cái thau); hay ghé thăm ai.

[vi] Trổ đòng là khi lúa ra hoa, cả cánh ruộng rất thơm và đẹp dịu dàng. 
[vii] Bà Ngoại tôi làm bánh tét rất ngon. Từ nhỏ, tôi đặc biệt mê bánh tét nhưn chuối Bà làm với nếp, dừa, chuối, và dây lát do chính gia đình trồng. Từ khi xa nhà, tôi không được ăn bánh tét chuối do Bà làm nữa.

\section{* For Little Auntie Hiếu \\ once upon a child \\ i follow Mom to visit you \\ the rain season crawls on \\ the dry season cracks up}

Poem 6: in Gram's blouse pocket—-trong túi áo Ngoại

how i remember my care-free years

your blouse pocket is my safe storage

i entrust my most redolent stuff

and my most prized possessions

your white short-sleeved blouse

that has turned brown

from the stilt of the sour-salty soil

in the fields

away from home, i become a mother

and wear my white short-sleeved blouse

my lil' one follows me round

and trusts his treasure trove in my pocket

in Gram's pocket

are my spare coins

my bonbon

my pebbles

there is a hundred-year-old love

the blooming rice flowers

the intergenerational milk duct

the rice-field crabs salt-fried

the banana rice cakes

childhood memories

life spreading forth

next life, last life

all the toils that are shared

the pickled bean-sprouts and cabbage

the seduction of the first rice of the new season

in Gram's pocket are

endurance, bitterness

the toiling day in, day out 
the boundless flow of life

in Gram's pocket

i keep my entire life

now that we are in two worlds

i keep reaching but can't seem to touch it

* Riêng tặng Di Út Hiếu

ngày xưa con còn bé

hay theo mẹ về quê

mùa mưa trườn lê thê

mùa khô dồn nứt gót

con nhớ thời thơ dại

túi Ngoại là cái kho

con gửi những thơm tho

và những gì quý nhất

túi áo xưa của Ngoại

áo bà ba ráp-lăng

áo trắng nay sớm nâu

từ đất đồng chua mặn

xa nhà, con làm mẹ

cũng mặc áo bà ba

cu tí theo khắp nơi

gửi đồ trong túi mẹ

trong túi áo của Ngoại

có bạc cắc của con

có mấy cục bồ hòn

có mấy hòn đá cuội

có tình thương trăm tuổi

có ruộng lúa trổ đòng

có dòng sữa cộng thông

có cua đồng rang muối

có đòn bánh tét chuối

có kỷ niệm tuổi thơ

có cuộc đời đang chờ

có kiếp sau, kiếp trước

có nhọc nhằn san sớt

nồi bắp dẻo đầu mùa

có cải giá nhận chua

nôn nao cơm gạo mới

trong túi áo của Ngoại 
có chịu đựng, đắng cay có lam lũ từng ngày có thênh thang mạch sống

trong túi áo của Ngoại

con cất cả cuộc đời giờ sinh tử hai nơi con với hoài không chạm

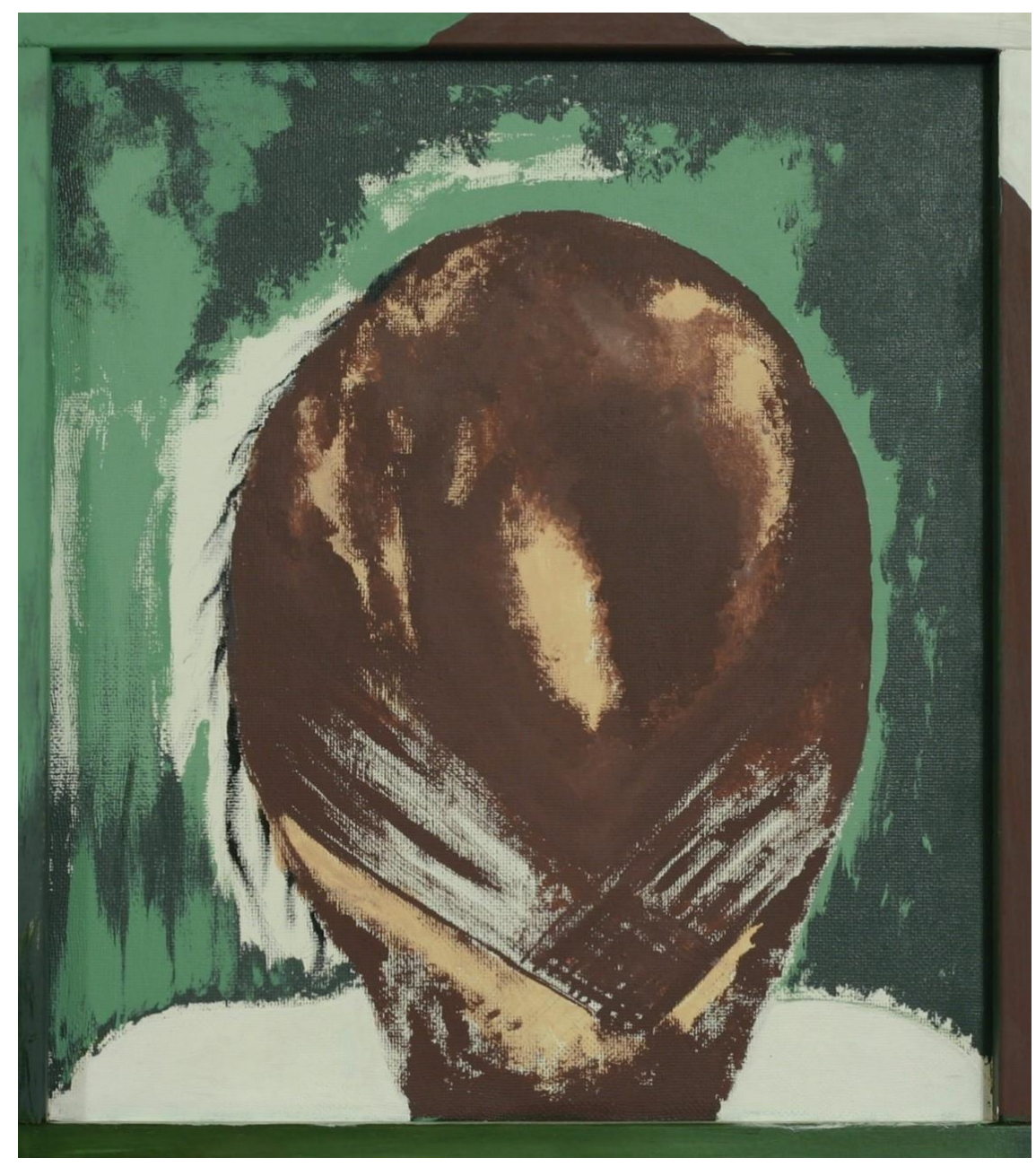

Note: A memory piece of Grandma painted when she was still alive, for the Vietnamese American Women Art Festival in Little Saigon in 2004. 


\section{About the Author}

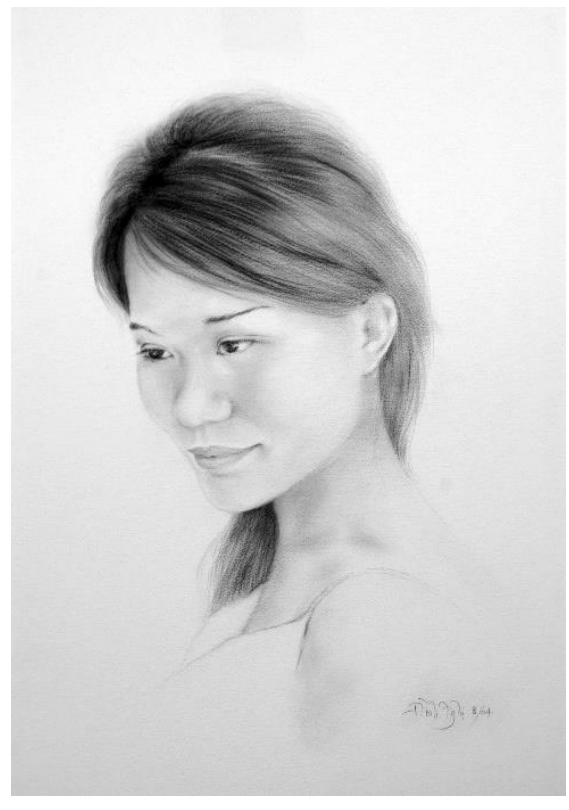

Trangdai Glassey-Tranguyen, an award-winning and multilingual researcher, and is the sole scholar having conducted hundreds of oral history interviews and multi-sited research on the Vietnamese diasporas in the United States, Europe, Australia, and Asia since the 1990s. Trangdai is widely recognized for her advocacy, leadership, and community services. As the first scholar to conduct extensive ethnographic fieldwork and oral history projects in Little Saigon, Orange County, California, Trangdai received several awards for her studies. She won the 2004 California State University-system student research competition, Graduate level in the humanities, with the entry "Orange County, Yellow History: An intimate encounter with Vietnamese American lives" based on the groundbreaking Vietnamese American Project. An exceptional-ranking Fulbright scholar, she started the very first ethnography and oral history project on the Vietnamese populations in Sweden in 2004 entitled "Home in Stockholm: Vietnamese narratives of transnationalism." Since 2004, Trangdai extended her fieldwork to ten other European countries to gain a pan-European perspective about immigration and minority communities there. She initiated the Vietnamese Berlin Project in 2005 entitled, "Squatting in racialized Berlin: Vietnamese diasporic subjectivity in a climactic double division." Trangdai holds an M.A. in History from California State University Fullerton with two campuswide outstanding awards, an M.A. in Anthropology from Stanford University with a thesis focusing on brokeraged Vietnamese brides, and an M.A. in Southeast Asian Studies from University of California Riverside, focusing on undocumented mobilities of Vietnamese immigrants in Berlin. She is completing her dissertation on Vietnamese American political subjectivities in Orange County, CA.

A celebrated and syndicated bilingual author, Trangdai has published over 3,000 poetic, creative, translation, and critical works in/as academic journals, K-12 texts, anthologies, edited volumes, and the media worldwide. She has authored five books of bilingual poetry, and her poems have been translated into thirteen languages. Trangdai has taught, researched, published, and presented in Vietnamese and English on topics and in programs pertaining to the Vietnamese language, culture, and diasporas for the last twenty six years at K-12 and university levels. In the last ten years, she has diligently advocated for dual immersion Vietnamese-English education in public schools, and has served as a bicultural bilingual consultant for biliteracy programs. In early 2015, she published over 50 Vietnamese texts with audio recordings for Kindergarten and first grade levels with National Resource Center for Asian Languages (NRCAL) at California State University Fullerton. 


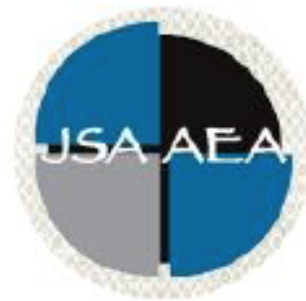

Vol.15 Iss.1 (2020)

\title{
Journal of Southeast Asian American Education and Advancement
}

\author{
www.JSAAEA.org
}

\section{Editor}

Dr. Wayne E. Wright

Purdue University

Associate Editors

Dr. Chhany Sak-Humphry

University of Hawaii at Manoa

Dr. Phitsamay Sychitkokhong Uy

University of Massachusetts, Lowell

\section{Book Review Editor \\ Dr. Vichet Chhuon}

University of Minnesota

Creative Works Editor

Bryan Thao Worra

Lao Assistance Center

\section{Journal Manager \\ Fang Gao \\ Purdue University}

\section{Editorial Review Board}

Dr. Steve Arounsack

California State University, Stanislaus

Dr. Sovicheth Boun

Salem State University

Dr. Virak Chan

Purdue University
Dr. Carl L. Bankston III

Tulane University

Dr. Phala Chea

Lowell Public Schools

Dr. George Chigas

University of Massachusetts, Lowell 


\author{
Dr. Loan Dao \\ University of Massachusetts Boston \\ Dr. Changming Duan \\ University of Missouri-Kansas City \\ Dr. Sothy Eng \\ Lehigh University \\ Dr. Vincent K. Her \\ University of Wisconsin, Eau Claire \\ Dr. Peter Nien-Chu Kiang \\ University of Massachusetts, Boston \\ Dr. Kevin K. Kumashiro \\ University of Illinois, Chicago \\ Dr. Ha Lam \\ Independent Scholar \\ Dr. Jonathan H. X. Lee \\ San Francisco State University \\ Dr. Monirith Ly \\ Royal University of Phnom Penh \\ Dr. Bic Ngo \\ University of Minnesota \\ Dr. Leakhena Nou \\ California State University, Long Beach \\ Dr. Mark Pfeifer \\ SUNY Institute of Technology \\ Dr. Loan T. Phan \\ University of New Hampshire \\ Dr. Karen Quintiliani \\ California State University, Long Beach \\ Dr. Angela Reyes \\ Hunter College \\ The City University of New York \\ Dr. Fay Shin \\ California State University, Long Beach \\ Dr. Christine Su \\ College of San Mateo \\ Dr. Alisia Tran \\ Arizona State University \\ Dr. Khatharya Um \\ University of California, Berkeley \\ Dr. Kim Tran \\ University of California, Los Angeles, \\ Glendale Community College \\ Dr. Molly Wiebie \\ The University of Texas at Austin
}

Dr. Hien Duc Do

San Jose State University

Dr. Sophal Ear

Occidental College

Dr. Jeremy Hein

University of Wisconsin, Eau Claire

Dr. Nancy H. Hornberger

University of Pennsylvania

Dr. Peter Tan Keo

New York University

Dr. Yvonne Kwan

San Jose State University

Dr. Ravy Lao

California State University, Los Angeles

Dr. Stacey Lee

University of Wisconsin, Madison

Dr. Sue Needham

California State University, Dominguez Hills

Dr. Max Niedzwiecki

Daylight Consulting Group

Dr. Clara Park

California State University, Northridge

Dr. Giang Pham

University of Massachusetts Amherst

Dr. Malaphone Phommasa

University of Clifornia Santa Barbara

Dr. Kalyani Rai

University of Wisconsin-Milwaukee

Dr. Cathy J. Schlund-Vials

University of Connecticut, Storrs

Dr. Nancy J. Smith-Hefner

Boston University

Dr. Yer J. Thao

Portland State University

Dr. Monica M. Trieu

Purdue University

Dr. Silvy Un

Saint Paul Public Schools

Dr. Linda Trinh Vo

University of California, Irvine

Dr. Yang Sao Xiong

The University of Wisconsin-Madison

Dr. Zha Blong Xiong

University of Minnesota 


\section{Doctoral Student Editorial Review Board}

\author{
Diana Chandara \\ University of Minnesota-TwinCiteis \\ Linh Dang \\ University of Rochester \\ Annie BichLoan Duong \\ San Joaquin County Office of Education \\ Jacqueline Mac \\ Indiana University \\ Vanessa Sovanika Na \\ University of California SanDiego \\ Khoi Nguyen \\ George Mason University \\ Linda Marie Pheng \\ University of Wisconsin-Madison \\ Latana Thaviseth \\ University of California Los Angeles \\ Melissa Vang \\ San Diego State University \\ Soua Xiong \\ San Diego State University \\ Claremont Graduate University
}

\author{
Kassandra Chhay \\ University of Minnesota-Twin Cities \\ Bao Diep \\ University of Minnesota-Twin Cities \\ Nielson Hul \\ Cornell University \\ Dung Minh Mao \\ University of Minnesota-Twin Cities \\ Hoa Nha Nguyen \\ Boston College \\ Thien-Huong Ninh \\ University of Southern California \\ Krissyvan Truong \\ Claremont Graduate University \\ Mai Vang \\ University of Massachusetts Boston \\ Thong Vang \\ University of Minnesota-Twin Cities
}

